\title{
Focus on Gonadotrophin Signalling
}

\section{An update of the pathophysiology of human gonadotrophin subunit and receptor gene mutations and polymorphisms}

\author{
Axel P N Themmen \\ Department of Internal Medicine, Erasmus MC, PO Box 1738, 3000 DR Rotterdam, The Netherlands \\ Correspondence should be addressed to A P N Themmen; Email: a.themmen@erasmusmc.nl
}

\begin{abstract}
New information about mutations and polymorphisms in the genes for the gonadotrophins and their receptors has become available in the last few years. In this short review mutations and polymorphisms in gonadotrophins, their receptors and their patho-physiological effects and implications are discussed. An increasingly clear picture about the structure-function relationships of gonadotrophin action is emerging from the combining the types and the locations of the mutations with their phenotypic effects and the information about the crystal structure of these molecules.

Reproduction (2005) 130 263-274
\end{abstract}

\section{Introduction}

The most recent comprehensive overview of mutations in gonadotrophin subunit and receptor genes and their pathophysiological consequences was published some 5 years ago (Themmen \& Huhtaniemi 2000). Since the knowledge in this field has expanded considerably during the past years I will present here an update on the information in the field that has accumulated in the last 5 years since the publication of the review.

The general principles of pathophysiological consequences of mutations and polymorphisms affecting gonadotrophin action will be introduced, followed by the recent advances in the field. New polymorphisms and mutations that have been detected in the genes for luteinising hormone ( $\mathrm{LH})$ and follicle-stimulating hormone (FSH) and their receptors ( $\mathrm{LH}$ receptor and $\mathrm{FSH}$ receptor) will be discussed in detail. In Themmen and Huhtaniemi (2000) a comprehensive overview of the topic up to the year 2000 can be found. That paper contains extensive tables and figures specifying most of the mutations and variants of the common- $\alpha$, $L H \beta$, $\mathrm{FSH} \beta$, LH receptor and FSH receptor genes.

\section{Functional consequences of mutations and polymorphisms affecting gonadotrophin action}

\section{Gonadotrophin receptors}

The $\mathrm{LH}$ and $\mathrm{FSH}$ receptors together with their homologue the receptors for thyrotrophin-stimulating hormone (TSH), constitute the family of glycoprotein hormone receptors, a subfamily of the large group of $\mathrm{G}$ protein-coupled receptors (GPCRs). The TSH and $\mathrm{FSH}$ receptors (gene names: TSHR and FSH receptor) both have a single ligand, TSH and FSH respectively, whereas the LH receptor binds both $\mathrm{LH}$ and chorionic gonadotrophin (hCG in humans), an LH analogue produced by the placenta during pregnancy in primates and equine species. The $\mathrm{LH}$ receptor is therefore also known as the LH/CG receptor (gene name: LHCGR). These receptors have a rhodopsinlike transmembrane (TM) domain (Palczewski et al. 2000, Themmen \& Huhtaniemi 2000, Dias \& Van Roey 2001, Ascoli et al. 2002, Szkudlinski et al. 2002) in common with the superfamily of GPCRs. In addition, they have a large N-terminal extracellular domain (ECD; 359-414 amino acid residues; homology $\sim 40 \%$ ), which conveys specific hormone binding to the receptors (Braun et al. 1991, Cornelis et al. 2001, Remy et al. 2001). The TMs of individual glycoprotein hormone receptors appear to be functionally interchangeable and display high sequence homology $(\sim 70 \%)$ between the different glycoprotein hormone receptors.

Based on sequence analysis and comparison with other proteins (Kobe \& Deisenhofer 1993), the ECDs of the glycoprotein hormone receptors were suggested to contain nine leucine-rich repeats (LRR) flanked by $\mathrm{N}$ - and C-terminal cysteine-rich regions. LRR motifs have been recognized in a large number of distinct proteins (Kobe \& Kajava 2001) and are thought to form a horseshoe-like structure. 
Together, these repeats form a flat concave surface consisting of short $\beta$ turns to which the large ligand can bind. This structure is stabilized by short, parallel $\alpha$-helical stretches that connect the beta-strands. The hormone binds to the $\beta$ surface using multiple contact points and the helical segments are aligned to form the outer convex side of the ECD (Jiang et al. 1995, Kajava et al. 1995, Bhowmick et al. 1996).

Very recently, the report of the crystal structure of a complex of FSH with the ECD of the FSH receptor has corrected and further refined the existing models (Fan \& Hendrickson 2005). This report shows that the $\beta$-sheet contains 9 parallel strands and a 10th that is contributed by the N-terminal cystine repeat. Furthermore, the curvature of the hormonebinding concave $\beta$-sheet is less strong (Fan \& Hendrickson 2005). In the FSH-FSH receptor crystal, FSH is positioned in the $\mathrm{FSH}$ receptor tube formed by the concave $\beta$-sheet with its long axis perpendicular. The structure also suggests that the $\mathrm{FSH}$ receptor may either dimerize upon $\mathrm{FSH}$ binding, or may exist as a pre-formed dimer complex without ligand. In addition, the crystal reveals detailed information on the identity of the amino acids that are involved in the interaction between $\mathrm{FSH}$ and its receptor. The seat belt structure of FSH (see below) is directly involved in hormone-receptor interaction (Fan \& Hendrickson 2005).

\section{Gonadotrophin subunits}

The glycoprotein hormones are heterodimers, each consisting of an $\alpha$ and a $\beta$ subunit. The $\alpha$ subunit is identical in all hormones, whereas the $\beta$ subunit confers the specificity to the hormone (Themmen \& Huhtaniemi 2000). The crystal structures of deglycosylated hCG and FSH are known (Lapthorn et al. 1994, Fox et al. 2001) and, as expected, they are very similar. Although the $\alpha$ and $\beta$ subunits show no amino acid sequence similarity, their three-dimensional structures are remarkably similar, having an elongated shape defining the long axis with two $\beta$-hairpin loops on one side and a single hairpin loop on the other side. The $\beta$ hairpins are stabilized by disulphide bridges. The $\alpha$ and $\beta$ subunits form an elongated slightly curved structure and are non-covalently associated in a head-to-tail orientation by means of a cystine knot motif. Thus, the gonadotrophins are members of the superfamily of cystine knot growth factors. Other members include nerve growth factor, transforming growth factor- $\beta$ and platelet-derived growth factor$\beta$. The cystine knot motif is characterized by a cluster of three cystine disulphide bonds in each subunit. The cystine knot consists of an eight amino acid ring through which an intra-subunit disulphide bond is formed. The $\alpha-\beta$ dimer is held together by a 'seatbelt' structure formed by the C-terminal amino acids of the $\beta$ subunit wrapped around the $\alpha$ subunit and stabilized by one of the disulphide bonds. Both the association of the subunits and the binding of the heterodimer to the receptor are dependent on this seatbelt.

Extensive studies on site-directed mutagenesis have unravelled the role of a number of amino acids in the tertiary structure of this subunit, including the structures necessary for glycosylation, proper folding, heterodimerization with the $\beta$ subunit and receptor binding and signal transduction of the dimeric hormone.

\section{Mutations and polymorphisms in human luteinizing hormone and its receptor \\ $L H$ receptor}

As reviewed previously (Themmen \& Huhtaniemi 2000), $\mathrm{LH}$ receptor mutations (Fig. 1) can be activating, causing precocious puberty in boys, and inactivating, disrupting sex differentiation in men and causing anovulation in women. In the following sections, we will review the recent new mutations that have been described in the $\mathrm{LH}$ receptor gene.

\section{Activating $\mathrm{LH}$ receptor mutations}

A missense Leu368Pro mutation located in the first transmembrane helix of the transmembrane domain was found in two Brazilian brothers showing typical precocious puberty at an early age (2 and 3 years of age) (Latronico et al. 2000). In vitro expression of this mutant showed a similar pattern to many of the mutant $\mathrm{LH}$ receptors that are constitutively active (Themmen \& Huhtaniemi 2000). Thus, CAMP production was increased in the absence of added hCG, and at higher hCG concentrations the receptor responded with further increases in CAMP, never reaching the levels attained at maximal response in the non-mutant $\mathrm{LH}$ receptor. As noticed in other families (Rosenthal et al. 1996), the mother of these two sons was also a carrier of the mutation, indicating that carriership of an activating mutation in the $\mathrm{LH}$ receptor gene has no adverse effects on female infertility (Latronico et al. 2000).

Amino acid Asp578 in the $\mathrm{LH}$ receptor deserves special discussion with respect to activating $\mathrm{LH}$ receptor mutations. Asp578Gly is one of the most common activating mutations found in the $\mathrm{LH}$ receptor gene (Shenker et al. 1993, Laue et al. 1995), while tyrosine (Tyr) or glutamate (Glu) at this position also cause precocious puberty (Laue et al. 1995, 1996). However, Asp578His causes Leydig cells to undergo transformation and their increased growth results in adenoma formation (Liu et al. 1999). Interestingly, this mutation appears only to occur somatically, i.e. it is found only in the Leydig tumours themselves, but not in the germ line. Other case reports describe the same mutation (Canto et al. 2002, RichterUnruh et al. 2002b), while another two studies on sex cord tumours failed to reveal any $\mathrm{LH}$ receptor mutations (Giacaglia et al. 2000, Vieira et al. 2002), indicating that not all Leydig cell adenomas are caused by the Asp578His somatic mutation in the $\mathrm{LH}$ receptor gene.

Another $\mathrm{LH}$ receptor mutation in the 2 nd transmembrane $\alpha$-helix, Met398Thr, has been reported in case reports (Ignacak et al. 2000, 2002). This mutation is of 


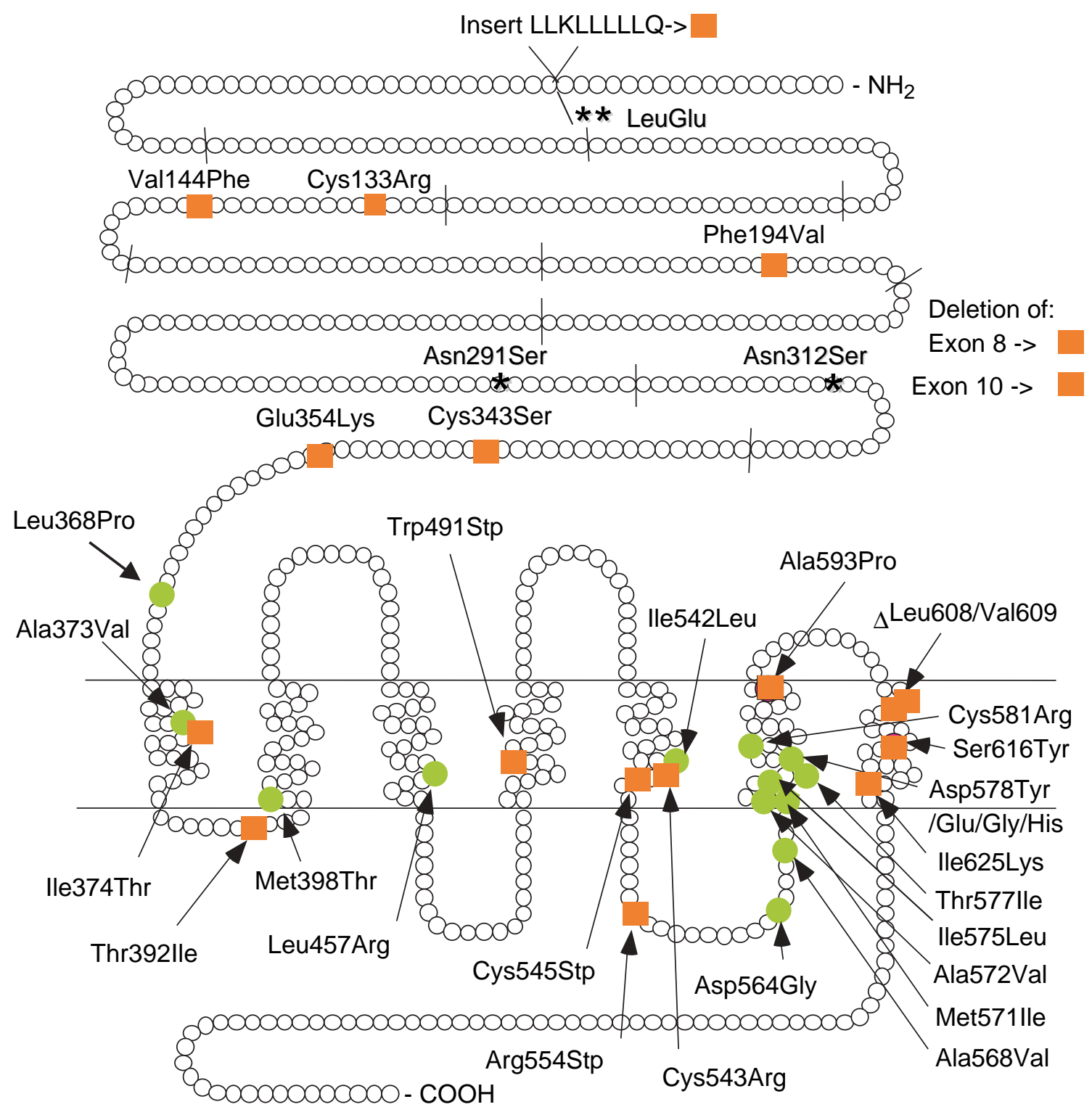

Figure 1 The currently known mutations and amino acid altering polymorphisms in the human LH receptor gene. The green circles depict the activating mutations, the red squares inactivation mutations, and the asterisks the polymorphisms. Stp = nonsense (stop) codon.

special interest, since it shows incomplete penetrance, i.e. not all male family members that are carriers of the mutation show the precocious puberty phenotype (Evans et al. 1996). It will be of interest to study these families in more detail, since the incomplete penetrance may indicate interaction with a modifier gene that silences the activating effects of the amino acid change in the $\mathrm{LH}$ receptor.

\section{Inactivating $\mathrm{LH}$ receptor mutations}

Inactivating mutations can take many forms (Themmen \& Huhtaniemi 2000) - large partial gene deletions to smaller deletions of just two amino acids and nonsense mutations resulting in truncated $\mathrm{LH}$ receptor protein have been described. As an example, the homozygous insertion of one base pair ( $\mathrm{T}$ ) at codon 589 can be mentioned (Richter-Unruh et al. 2005). This insertion causes a frameshift in the $\mathrm{LH}$ receptor gene resulting in a truncated $\mathrm{LH}$ receptor protein. The functional consequences of this truncation were not tested in vitro. The patient, a 46XY patient with complete pseudohermaphroditism, showed lack of responsiveness to $\mathrm{LH} / \mathrm{hCG}$ with concomitant undetectable serum testosterone (Richter-Unruh et al. 2005).

Inactivating $\mathrm{LH}$ receptor mutations have also been identified in the extracellular hormone-binding domain. In a complete 46XY pseudohermaphrodite patient a very low number of testicular Leydig cells was found accompanied by a low LH receptor expression (Gromoll et al. 2002). The patient was found to be homozygous 
for a missense Phe194Val mutation located in exon 7 in a motif that is conserved in the glycoprotein hormone receptor family. The Phe194Val LH receptor did not respond at all to hCG in vitro. Phe194 is located in an interesting motif, AFNGT, conserved in the gonadotrophin receptors. N195GT is a glycosylation motif and the change of the homologous Ala189 in the FSH receptor to Val, identified in some patients with hypergonadotrophic ovarian dysgenesis (Aittomäki et al. 1995), causes complete inactivity of the FSH receptor due to intracellular sequestration of the mutant receptor protein (Rannikko et al. 2002). An Asn191lle change in the FSH receptor, which was found in a heterozygous patient without phenotype, leads to decreased coupling to the cAMP pathway (Gromoll et al. 1996b).

From the same group an interesting follow-up to the del(exon 10) LH receptor mutant has been published. This deletion was originally described in a patient who had normal male sex differentiation, but did not show signs of puberty, apparently because the del(exon10) LH receptor did not respond to $\mathrm{LH}$, while it was sensitive to hCG, hence the intact male sex differentiation (Gromoll et al. 2000). Indeed, in vitro expression of the del(exon10) LH receptor shows a nearly normal response to hCG whereas the dose-response relationship for LH is severely shifted to the right (Muller et al. 2003). The human del(exon10) LH receptor mutation has an interesting parallel in the marmoset monkey. The marmoset uses CG $\beta$ rather than $\mathrm{LH} \beta$ for $\mathrm{LH}$ receptor stimulation. The marmoset pituitary does not express LH $\beta$ (Muller et al. 2004). Concomitantly, the marmoset monkey $\mathrm{LH}$ receptor always misses the amino acids equivalent to the exon 10 encoded amino acid residues (Zhang et al. 1997). The authors propose that owing to an unknown mutational event in evolution, expression of marmoset LH was completely abolished, and marmoset CG which, unlike $\mathrm{LH}$, acts normally even when exon 10 is missing from the $\mathrm{LH}$ receptor - took over its function.

A homozygous Val144Phe mutation in the LH receptor gene was found in a 46XY patient with an almost complete female phenotype. In vitro, the mutant $\mathrm{LH}$ receptor protein was not transported to the plasma membrane. Inability of the protein to be transported to the cell surface has also been shown with some other missense or truncation mutations such as Cys343Ser, Cys543Arg (Martens et al. 2002), Leu502Pro (Leung et al. 2004) and Tyr612Stop (Salameh et al. 2005).

Both Val144 and Phe194 are thought to be located (based on a previously published model of the extracellular domain of the LH receptor; Jiang et al. 1995) on the convex side of the leucine-rich repeat domain of the $\mathrm{LH}$ receptor protein (Val144 in the 4th helical segment; Phe194 in the 6th), so apparently are not directly involved in ligand binding.

\section{LH receptor polymorphisms}

The $\mathrm{LH}$ receptor gene carries a large number of single nucleotide polymorphisms (SNPs). According to the SNPper website (http://SNPper.chip.org) 282 SNPs are found in the $\mathrm{LH}$ receptor gene, resulting in an average distance between SNPs of 306 base pairs. Exact allele frequencies are not available for most of these polymorphisms. The most frequent $\mathrm{LH}$ receptor polymorphisms that involve an amino acid change are the absence or presence of a two amino acid insertion at position 18 in exon1 (insLQ; allele frequency 29\%), and two variable amino acids at position 291 and 312 respectively: N291S (S allele: 10\%) and N312S ( $\mathrm{N}$ allele: 45\%) (RichterUnruh et al. 2002a). In addition, an R124Q has been described as an SNP but with low frequency. Powell and coworkers (2003) recently reported that breast cancer patients have a significantly worse overall survival when they are either homozygous or heterozygous carriers of the insLQ allele (Hazard Ratio 2.4; $P=0.006$ ) (Powell et al. 2003). In addition, trends were observed for associations between the insLQ carriers and nodal involvement or larger tumour size. These results indicate that the insLQ polymorphic insertion probably has an effect on $\mathrm{LH}$ receptor protein function, although one report showed that in vitro hCG signal transduction of the two LH receptor variants was not different (Rodien et al. 1998b). The finding of an association of breast cancer disease with insLQ needs independent confirmation. A plausible explanation for the observed association of insLQ with breast cancer could be through an effect of $\mathrm{LH}$ through the $\mathrm{LH}$ receptor, with or without insLQ, causing an increase in the levels of oestrogens in the serum, which, in turn, may stimulate breast cancer cells and therefore cause recurrence of the disease. Alternatively, direct effects of LH on breast cancer cells themselves have been suggested (Guo et al. 2004). Since LH is a major regulator of ovarian steroid hormone production, further investigations are needed into the possible role of the polymorphism in other steroid hormone-related diseases. These include prostate cancer in the male and oestrogenrelated disease endpoints such as bone density or fractures in elderly women.

\section{$L H \beta$ subunit}

As yet, only a few mutations are known in the gonadotrophin subunit genes (Fig. 1). None of these mutations are activating the genes, all appear to be loss-of-function mutations. Two subjects with $\mathrm{LH} \beta$ and 7 with $\mathrm{FSH} \beta$ inactivation have been described in the literature (Themmen \& Huhtaniemi 2000, Layman et al. 2002, Valdes-Socin et al. 2004). Conspicuously, no germ line mutations in the common- $\alpha$ subunit or hCG $\beta$ subunits are known. The reason may be that such mutations would inactivate chorionic gonadotrophin (hCG), which may be embryo lethal, or even incompatible with implantation. 


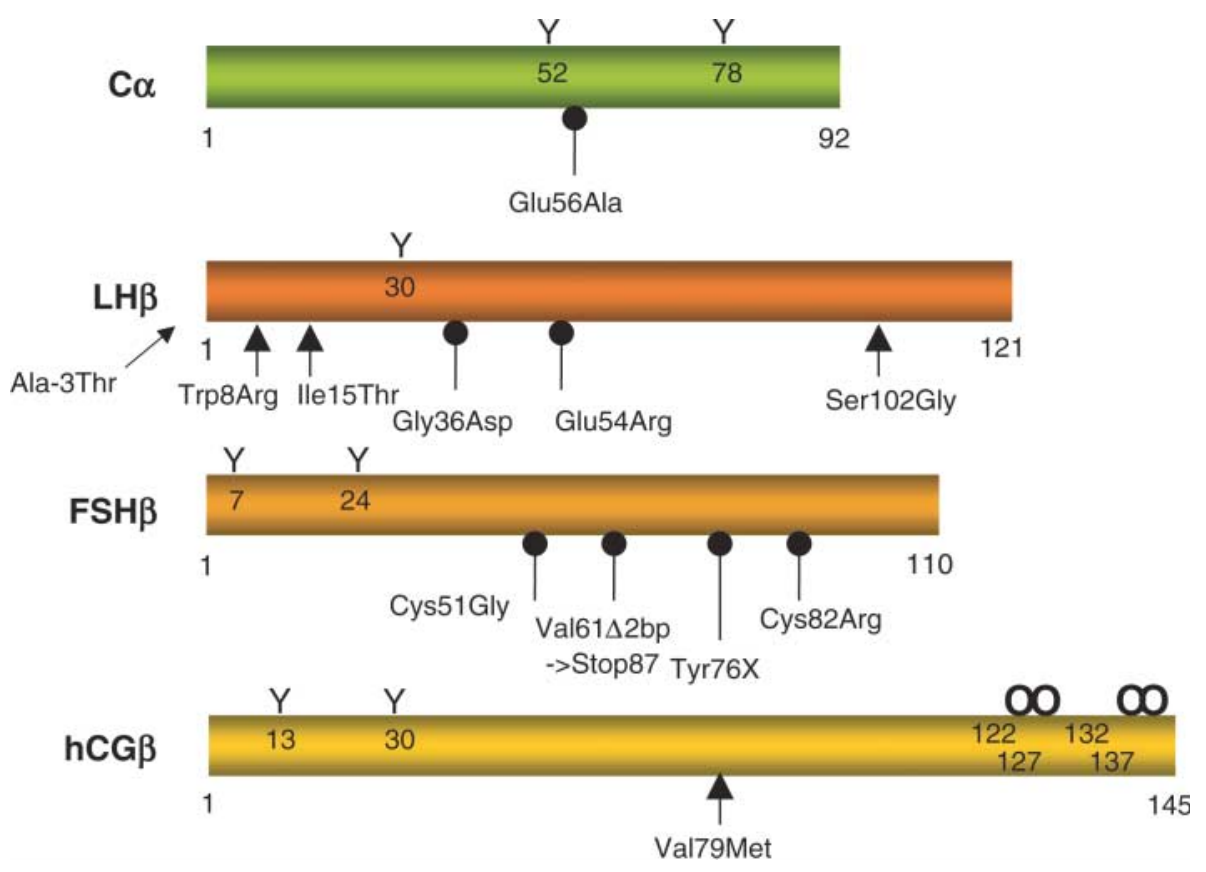

Figure 2 The currently known mutations and amino acid altering polymorphisms in the common $\alpha$-subunit (C $\alpha)$, LH $\beta$, FSH $\beta$ and hCG $\beta$ genes. For references and further details, see text. Arrow, polymorphism; line with closed circle, inactivating mutation.

\section{$L H \beta$ mutations}

Compared with the rare loss-of-function $\mathrm{LH}$ receptor mutations $(n=17)$, mutations in the LH $\beta$ gene (Fig. 2) have proven to be very rare. Only the second report of a homozygous carrier of a missense inactivating mutation in the $\mathrm{LH} \beta$ gene was published recently (Valdes-Socin et al. 2004). In the hypogonadal 30-year-old 46XY patient, low circulating $\mathrm{LH}$ was found with concomitant reduced spermatogenesis and hypoplastic Leydig cells, hallmarks of absent LH signalling as found in patients with inactivating LH receptor gene mutations (Valdes-Socin et al. 2004). The patient's mutant Gly36Asp LH $\beta$ was expressed in vitro together with the common- $\alpha$ subunit, and showed absence of $\alpha / \beta$ heterodimerization and therefore no $\mathrm{LH}$ bioactivity (Valdes-Socin et al. 2004). The Gly36Asp in the LH $\beta$ subunit disrupts a 5 -amino acid motif that allows the formation of a cystine knot (see above). In the absence of the cystine knot structure no dimerization can occur, and no bioactive $\mathrm{LH}$ can be produced.

This effect of the mutation is different from the other published inactivating $\mathrm{LH} \beta$ mutation (Weiss et al. 1992). In this case the Gln54Arg abolished interaction of the $\mathrm{LH} \alpha / \beta$ dimer with the $\mathrm{LH}$ receptor, resulting in delayed puberty and absent testosterone production and spermatogenesis in the patient (Weiss et al. 1992). Both LHß mutations illustrate the role of $\mathrm{LH}$ during sex differentiation. Apparently, LH is not necessary for male differentiation before birth, since both patients had a male phenotype and descended testes. The fetal activation of Leydig cell proliferation, differentiation and testosterone production is taken care of by placental hCG, allowing these patients to undergo fetal male sex differentiation and insulin-like factor 3-mediated testis descent.

\section{LH $\beta$ polymorphisms}

The best-studied polymorphism in the LH $\beta$ gene is a combination of two SNPs (T82C/T104C) that are in complete linkage disequilibrium and results in a combination of two amino acid changes: Thr8Arg/lle15Thr (Furui et al. 1994, Pettersson et al. 1994). This polymorphism (V-LH) is found worldwide at highly variable frequencies in cohorts studied from different countries and different ethnic groups. Most recent association studies of the $\mathrm{V}$ - $\mathrm{LH} \beta$ gene polymorphism were carried out using relatively small cohorts or were case reports (Okuno et al. 2001, Takahashi et al. 2000a, 2001). The V-LH polymorphism can be studied in two ways: using PCR-based techniques that analyse the polymorphisms at the DNA level, and using an ELISA based on a specific antibody that does not recognize V-LH and therefore reports lower $\mathrm{LH}$ levels than do other assays (Pettersson et al. 1992). Several studies were conducted to investigate possible effects of the two amino acid changes on $\mathrm{LH}$ function and to identify possible associations with disease endpoints (reviewed in Themmen \& Huhtaniemi 2000). No association of the V-LH $\beta$ allele with infertility was found in cohorts of 95 male infertility patients (Lee et al. 2003), in a comparison of 145 infertile with 200 fertile men (Ramanujam et al. 2000), or in association studies of several endocrine-related cancers (Cramer et al. 2000, Powell et al. 2003). Nevertheless, V-LH appears to have functional effects, since in a study of 40 healthy Japanese women, $\mathrm{V}$ - $\mathrm{LH} \beta$ carriers appeared to respond to 
a gonadotrophin-releasing hormone challenge with a higher maximal LH response (Takahashi et al. 2000b). Further evidence for the functional differences of $\mathrm{V}$ - $\mathrm{LH}$ from normal LH was obtained by comparing the in vitro and in vivo behaviour of recombinant forms of the two hormones. $\mathrm{V}$-LH displayed higher biopotency in vitro, whereas its half-life in the circulation was shorter than that of normal LH (Manna et al. 2002). Moreover, the carbohydrate side chain composition of V-LH was clearly different, suggesting different pathways in its intracellular processing.

A second polymorphic variant of the $\mathrm{LH} \beta$ gene is an SNP that causes a Gly102 to Ser amino acid change (Lamminen et al. 2002). The frequency of this LH $\beta$ polymorphism appears to be low, and in cohorts from Finland, India, Denmark, Rwanda and Korea the Ser allele was absent (Kim et al. 2001, Lamminen et al. 2002, Lee et al. 2003). In one study (Singaporean Chinese), the Ser allele polymorphism was detected in infertile men (5 out of 145) but not in the fertile control group $(n=200)$ (Ramanujam et al. 2000).

A third polymorphic variant of the $\mathrm{LH} \beta$ gene was identified by Jiang and colleagues (2002). This SNP causes an Ala to Thr change three amino acid residues before the signal peptide cleavage site (Ala3Thr). The Thr variant appears to have slightly different in vitro signal transduction properties compared with the Ala-containing $\mathrm{LH} \beta$ protein, although the mature proteins are essentially identical with respect to their amino acid composition. Thus, $\mathrm{Ser}^{-3} \mathrm{LH} \beta$ was more potent in stimulating CAMP in treated cells, whereas the $\mathrm{Thr}^{-3} \mathrm{LH} \beta$ appears to be more effective in stimulating phosphatidylinoside (PI) turnover (Jiang et al. 2002).

One possible polymorphism in the hCG $\beta$ gene has been reported, an SNP that causes a change from Val to Met at position 79 (Fig. 2) (Miller-Lindholm et al. 1999). In this report the frequency of the Met allele appeared to be quite high (4.2\%). Upon in vitro expression in cultured cells Met79-LH $\beta$ was unable to fold correctly and this resulted in impaired ability to associate with the $\alpha$ subunit, suggesting that the Met79 allele may have deleterious effects. However, when the same polymorphism was searched for in 580 DNA samples from 4 European populations, not a single case was found (Jiang et al. 2004). The real frequency and significance of this polymorphism thus remains unknown.

\section{Mutations and polymorphisms in human follicle- stimulating hormone and its receptor \\ FSH receptor}

As with the $\mathrm{LH}$ receptor gene, $\mathrm{FSH}$ receptor gene mutations exist, in principle, in gain-of-function or activating and in loss-of-function or inactivating forms (Fig. 3). Until now only one case of an activating FSH receptor mutation has been described in a case of persistent spermatogenesis of a hypophysectomized man (Gromoll et al. 1996a). The number of inactivating $\mathrm{FSH}$ receptor mutants is slowly increasing.

\section{Activating $\mathrm{FSH}$ receptor mutations}

Whereas no additional activating FSH receptor mutations have been described, in vitro FSH receptor mutagenesis showed that such amino acid changes are certainly possible (Tao et al. 2000). It remains to be established whether activating $\mathrm{FSH}$ receptor mutations cause a phenotype other than the very special case of the hypophysectomized man in which the single $\mathrm{FSH}$ receptor mutation was detected (Gromoll et al. 1996a) and searches for activating $\mathrm{FSH}$ receptor mutations in candidate diseases, such as premature ovarian failure, ovarian tumours, megalotestes, precocious puberty and twin pregnancies have been unsuccessful (Giacaglia et al. 2000, Montgomery et al. 2000, de la Chesnaye et al. 2001, Takakura et al. 2001, Tong et al. 2001, Sundblad et al. 2004). An animal model for an activating $\mathrm{FSH}$ receptor mutation would be seminal in resolving this intriguing question.

The similarity of the glycoprotein hormones makes the receptors vulnerable to mutations that would relax ligand specificity, especially during early pregnancy when hCG levels in women are extremely high. Indeed, such mutations have been described in the TSH receptor gene causing hCG-induced hyperthyroidism during pregnancy (Rodien et al. 1998a). Similarly, the FSH receptor may become sensitive to hCG during pregnancy causing ovarian hyperstimulation syndrome (OHSS). Such FSH receptor mutations were recently reported in women who had recurrent OHSS during consecutive pregnancies (Kaiser 2003, Smits et al. 2003, Vasseur et al. 2003, Montanelli et al. 2004). Expression of the mutant $\mathrm{FSH}$ receptors showed stimulation of CAMP production by hCG through the mutant FSH receptors (Kaiser 2003, Smits et al. 2003, Vasseur et al. 2003). In two of the cases (Asp567Asn and Thr449Ala), low levels of constitutive receptor activation and response of the mutated receptor to TSH were also found (Montanelli et al. 2004). The location of the mutations in the $\mathrm{FSH}$ receptor protein was surprising. Neither of the changed amino acids (Thr449lle, Ala and Asp567Asn) are located in the extracellular hormone binding domain, but rather in the transmembrane part of the FSH receptor. In addition, no high affinity hCG binding to the mutant receptors could be demonstrated. In one of the papers it is suggested that weakening of interhelical locks between the transmembrane helices by the mutations might make the receptor more vulnerable to low affinity activation by other glycoprotein hormones (Montanelli et al. 2004).

\section{Inactivating $\mathrm{FSH}$ receptor mutations}

Altogether 9 inactivating mutations are known in the human FSH receptor gene. The first one, Ala189Val, 


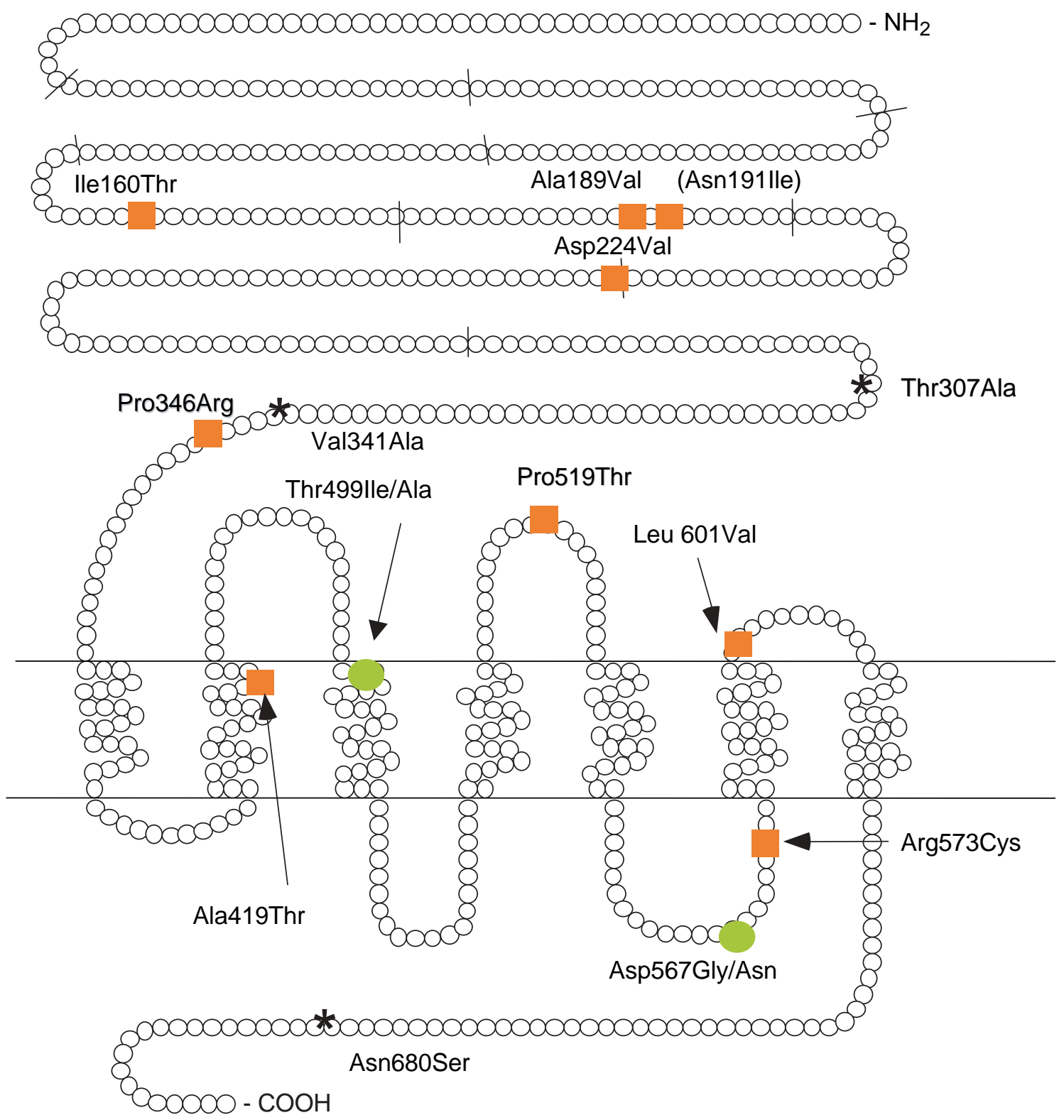

Figure 3 The currently known mutations and amino acid altering polymorphisms in the human FSH receptor gene. The green circles depict the activating mutations, the red squares inactivation mutations, and the asterisks the polymorphisms.

was described about 10 years ago (Aittomäki et al. 1995) in subjects of multiple Finnish families with a phenotype of hypergonadotrophic hypogonadism, primary or early onset secondary amenorrhoea, variable development of secondary sex characteristics and arrest of follicular maturation between the primordial and preantral stages. This mutation appears to be unique to the Finnish population. The mutant FSH receptor protein does not traffic to the plasma membrane, rendering the gene inactive (Rannikko et al. 2002). In addition, when homozygous Ala189Val FSH receptor patients were treated with massive doses of recombinant $\mathrm{FSH}$, no functional responses of the ovaries or testes were observed (Vaskivuo et al. 2002). A similar patient was described who was homozygous for a Pro419Thr mutation (Meduri et al. 2003). The affected female presented with hypergonadotrophic premature ovarian failure, very low oestrogen and inhibin B levels, and total lack of response to high doses of recombinant FSH. Pro419 is located in the 2 nd extracellular loop of the transmembrane domain in a conserved motif in the glycoprotein hormone receptors. Histological analysis of ovarian biopsies showed a similar pattern to that found in patients with the Ala189Val FSH receptor mutations: arrest of follicular maturation beyond the primary stage. Also this receptor was completely unable to traffic to the plasma membrane, reminiscent of many of the inactivating $\mathrm{LH}$ receptor mutants (see above). 
Other patients with $\mathrm{FSH}$ receptor gene mutations had less severe phenotypes, with secondary amenorrhoea, gonadotrophin resistance, normal ovarian size and presence of follicles up to the antral stage (Beau et al. 1998, Touraine et al. 1999). These patients were carriers of combinations of complete and partially inactivating mutations. Several additional $\mathrm{FSH}$ receptor mutations have recently been discovered, all in women. It appears that the male phenotype of inactivation of the $\mathrm{FSH}$ receptor gene is quite weak, with normal androgen production, reduced sperm quality but maintained fertility (Tapanainen et al. 1997).

A patient with a compound heterozygous mutation of Ala189Val and Ala419Thr was recently reported (Doherty et al. 2002). She appeared to be less affected than the homozygous Ala189Val patients described before (Aittomäki et al. 1995). At 17 years of age she had primary amenorrhoea, normal secondary sex characteristics, very low oestrogen levels but clear signs of endometrial oestrogen stimulation in transvaginal ultrasound investigation, and a normal progestin challenge test. The Ala419Thr FSH receptor bound $\mathrm{FSH}$ normally, but did not signal in vitro (Doherty et al. 2002).

The last mutation reported was a Pro348Arg substitution just outside the transmembrane domain of the receptor protein completely abolishing FSH binding, although it was not investigated whether this was due to intracellular sequestration of the receptor or to a genuine lack of ligand binding to a plasma membrane-expressed receptor (Allen et al. 2003). The female patient was hypergonadotrophic with delayed puberty and primary amenorrhoea.

Despite the rarity of the currently known FSH receptor mutations there is good correlation between the phenotype and the degree of receptor inactivation, as well as the site of mutation and its functional consequences, in the same fashion as with the larger number of LH receptor mutations (Themmen \& Huhtaniemi 2000). Mutations in the extracellular domain (Ile160Thr, Ala189Val, Asn191Ile, Asp224Val and Pro346Arg) completely abolish FSH receptor function and are found in the patients with the severest phenotypes. Transmembrane domain mutations (Ala419Thr, Arg573Cys and Leu602Val) have decreased but not completely abolished signalling and these patients have a less severe phenotype. Patients with milder mutations may still respond to high doses of FSH stimulation, and the molecular diagnosis of these rare patients may help in the design of a rational treatment for their infertility. All heterozygotes for the mutations so far studied have been free from phenotype, indicating that a single functional FSH receptor gene allele is sufficient for normal reproductive function.

\section{FSH receptor polymorphisms}

Besides the inactivating and activating mutations, a large number of SNPs have been identified in the human FSH receptor gene (http://www.ncbi.nlm.nih.gov/SNP/). The number is large, $>700$, but can be explained by the large size of the FSH receptor gene $(191 \mathrm{~kb})$, and the average SNP distance $(282 \mathrm{bp})$ is similar with that of the $\mathrm{LH}$ receptor (306 bp). The majority of the polymorphisms are intronic, 5 are located in the $\mathrm{FSH}$ receptor coding region and one in the promoter. The exonic polymorphisms are all in the transmembrane domain encoding exon 10 and all cause an amino acid change (Ala307Thr, Arg524Ser, Ala665Thr and Ser680Asn), except the SNP at codon 392 that is silent.

The best-studied polymorphisms in the $\mathrm{FSH}$ receptor gene are Ala307Thr and Ser680Asn, which have been found to be in linkage disequilibrium in most of the studies. The two most common allelic variants, Thr307/Asn680 and Ala307/Ser680, are almost equally distributed in Caucasian populations (Simoni et al. 2002). The other alleles represent less than $5 \%$ of the total. In several studies the association of the Ser680Asn polymorphism with endpoints that relate to FSH sensitivity have been investigated. Thus, the amount of FSH needed to reach similar oestradiol levels in in vitro fertilization (IVF) cycles was higher in women that carried the Ser680 FSH receptor allele, suggesting that the Ser680 FSH receptor allele encodes a less active $\mathrm{FSH}$ receptor protein that is less sensitive to FSH than the Asn680 allele (Perez Mayorga et al. 2000, Sudo et al. 2002, de Castro et al. 2003, 2004), although this finding could not be confirmed in all studies (Laven et al. 2003). In an association study of the Ser680 allele with OHSS (Daelemans et al. 2004), it was found that the Ser680 allele was enriched in a control IVF population compared with the general population, but that the OHSS population had even higher enrichment of this allele in comparison with controls (57 vs 39\%), which is difficult to reconcile with the suggested lower sensitivity of the Ser680 FSH receptor.

Some studies have shown an association of the Ser680 polymorphism with amenorrhoea or anovulation (Sudo et al. 2002, Laven et al. 2003) but no association with premature ovarian failure (Conway et al. 1999, Sundblad et al. 2004). Association studies with polycystic ovarian syndrome have yielded conflicting results in different populations (Conway et al. 1999, Tong et al. 2001, Sudo et al. 2002). Neither is there an association with twinning and the FSH receptor allele (Hasbargen et al. 2001), and no relationship to male fertility parameters has been found (Simoni et al. 1999, Asatiani et al. 2002). Recently, in a study of menstrual cycle parameters in women homozygous for either allele, an association of the Ser680 FSH receptor allele was found with higher FSH and lower inhibin A, oestradiol and progesterone in the luteo-follicular transition phase of the cycle, and a longer menstrual cycle (Greb et al. 2005). The Ser680 and Asn680 FSH receptor proteins appear to have identical characteristics upon in vitro expression, which leaves a molecular explanation for the observed clinical associations open for further research (Simoni et al. 1999, Sudo et al. 2002). 


\section{FSH $\beta$ subunit}

\section{FSH $\beta$ mutations}

A total of four different $\mathrm{FSH} \beta$ gene mutations have been published (Fig. 2). One of these involves a two base-pair deletion at codon 61 of the gene, causing a frame shift, premature stop and a truncation of the $\mathrm{FSH} \beta$ protein, rendering it completely inactive (Matthews et al. 1993). The second mutant, Tyr76X, also causes truncation of the protein (Layman et al. 2002) and in vitro expression of the mutant causes complete abrogation of both immuno- and bio-activity. The other two mutations, Cys51Gly and Cys82Arg (Themmen \& Huhtaniemi 2000) both affect cysteines involved in the cystine knot structure which is essential for dimerization and bioactivity of the $\mathrm{FSH} \beta / \alpha$ dimer (see above). The deletion mutants, in addition, lack the 'cystine noose' necessary for receptor recognition, and the seat belt domain needed to stabilise the $\mathrm{FSH} \beta / \alpha$ dimer. Hence, from the molecular point of view, the current knowledge about the genetic and crystalline structure of FSH provides sufficient background information to explain the hormone inactivation at the molecular level.

The patients with these inactivating $\mathrm{FSH} \beta$ mutations present with a phenotype that can be expected on the basis of the physiological function of FSH. Thus, the women all show sexual infantilism and infertility as a result of a lack of follicle growth and differentiation in the absence of bioactive FSH. However, the three men with FSH $\beta$ mutations are all normally masculinized but azoospermic (Lindstedt et al. 1998, Phillip et al. 1998, Layman et al. 2002). This phenotype is at variance with the male phenotype caused by $\mathrm{FSH}$ receptor mutations where, notwithstanding reduced sperm quality, fertility is maintained (Tapanainen et al. 1997).

The siblings with the Tyr76X mutation showed some evidence of puberty, whereas no residual bioactivity could be found in the studies by Layman et al. (2002) suggesting that other factors might preserve gonadal steroidogenesis in the absence of FSH or that current bioassays cannot discriminate among very low FSH levels.

All 4 women with inactivating $\mathrm{FSH} \beta$ gene mutations have largely similar phenotypes, which in the complete form includes absent puberty and infertility due to lack of follicular maturation. Other features are absence of breast development, primary amenorrhoea, low oestrogen production, undetectable serum FSH, and increased LH. As expected, a large number of undeveloped follicles, usually in the primordial stage but sometimes more advanced, can be found in the ovaries of the affected individuals. The two previously characterized men had azoospermia one had normal puberty and in the other puberty was delayed.

\section{FSH $\beta$ polymorphisms}

Somewhat surprisingly, and in contrast to $\mathrm{LH} \beta$, the FSH $\beta$ subunit appears to be highly conserved. Only a few silent polymorphisms in the exons and totally conserved promoter region were found in the $\mathrm{FSH} \beta$ gene when studied recently in 50 Danish and 50 Finnish DNA samples (I T Huhtaniemi, personal communication).

\section{Concluding remarks}

In the coming years one of the focuses of pathophysiological research in the gonadotrophin field will be on the association studies of gene polymorphisms with endpoints of disease in cohorts of sex differentiation and infertility patients, and other patients with aberrations of hormonal homeostasis. In this way also one of the important questions in the $\mathrm{LH}$ receptor field may be answered i.e. what, if any, is the role of the extra-reproductive system expression of the gonadotrophin receptors, especially the $\mathrm{LH}$ receptor. The author declares that there is no conflict of interest that would prejudice the impartiality of this scientific work.

\section{References}

Aittomäki K, Dieguez Lucena JL, Pakarinen P, Sistonen P, Tapanainen J, Gromoll J, Kaskikari R, Sankila E-M, Lehvaslaiho H, Reyes Engel A, Nieschlag E, Huhtaniemi I \& de la Chapelle A 1995 Mutation in the follicle-stimulating hormone receptor gene causes hereditary hypergonadotropic ovarian failure. Cell 82 959-968.

Allen LA, Achermann JC, Pakarinen P, Kotlar TJ, Huhtaniemi IT, Jameson JL, Cheetham TD \& Ball SG 2003 A novel loss of function mutation in exon 10 of the $\mathrm{FSH}$ receptor gene causing hypergonadotrophic hypogonadism: clinical and molecular characteristics. Human Reproduction 18 251-256.

Asatiani K, Gromoll J, Eckardstein SV, Zitzmann M, Nieschlag E \& Simoni M 2002 Distribution and function of FSH receptor genetic variants in normal men. Andrologia 34 172-176.

Ascoli M, Fanelli F \& Segaloff DL 2002 The lutropin/choriogonadotropin receptor, a 2002 perspective. Endocrine Reviews 23 $141-174$.

Beau I, Touraine P, Meduri G, Gougeon A, Desroches A Matuchansky C, Milgrom E, Kuttenn F \& Misrahi M 1998 A novel phenotype related to partial loss of function mutations of the follicle stimulating hormone receptor. Journal of Clinical Investigation 102 1352-1359.

Bhowmick N, Huang J, Puett D, Isaacs NW \& Lapthorn AJ 1996 Determination of residues important in hormone binding to the extracellular domain of the luteinizing hormone/chorionic gonadotropin receptor by site-directed mutagenesis and modeling. Molecular Endocrinology 10 1147-1159.

Braun T, Schofield PR \& Sprengel R 1991 Amino-terminal leucinerich repeats in gonadotropin receptors determine hormone selectivity. EMBO Journal 10 1885-1890.

Canto P, Soderlund D, Ramon G, Nishimura E \& Mendez JP 2002 Mutational analysis of the luteinizing hormone receptor gene in two individuals with Leydig cell tumors. American Journal of Medical Genetics 108 148-152.

de Castro F, Moron FJ, Montoro L, Galan JJ, Hernandez DP, Padilla ES, Ramirez-Lorca R, Real LM \& Ruiz A 2004 Human controlled ovarian hyperstimulation outcome is a polygenic trait. Pharmacogenetics 14 285-293.

de Castro F, Ruiz R, Montoro L, Perez-Hernandez D, Sanchez-Casas Padilla E, Real LM \& Ruiz A 2003 Role of follicle-stimulating 
hormone receptor Ser680Asn polymorphism in the efficacy of follicle-stimulating hormone. Fertility and Sterility 80 571-576.

de la Chesnaye E, Canto P, Ulloa-Aguirre A \& Mendez JP 2001 No evidence of mutations in the follicle-stimulating hormone receptor gene in Mexican women with 46,XX pure gonadal dysgenesis. American Journal of Medical Genetics 98 125-128.

Conway GS, Conway E, Walker C, Hoppner W, Gromoll J \& Simoni M 1999 Mutation screening and isoform prevalence of the follicle stimulating hormone receptor gene in women with premature ovarian failure, resistant ovary syndrome and polycystic ovary syndrome. Clinical Endocrinology 51 97-99.

Cornelis S, Uttenweiler-Joseph S, Panneels V, Vassart G \& Costagliola S 2001 Purification and characterization of a soluble bioactive amino-terminal extracellular domain of the human thyrotropin receptor. Biochemistry 40 9860-9869.

Cramer DW, Petterson KS, Barbieri RL \& Huhtaniemi IT 2000 Reproductive hormones, cancers, and conditions in relation to a common genetic variant of luteinizing hormone. Human Reproduction 15 2103-2107.

Daelemans C, Smits G, de Maertelaer V, Costagliola S, Englert Y, Vassart G \& Delbaere A 2004 Prediction of severity of symptoms in iatrogenic ovarian hyperstimulation syndrome by follicle-stimulating hormone receptor Ser680Asn polymorphism. Journal of Clinical Endocrinology and Metabolism 89 6310-6315.

Dias JA \& Van Roey P 2001 Structural biology of human follitropin and its receptor. Archives of Medical Research 32 510-519.

Doherty E, Pakarinen P, Tiitinen A, Kiilavuori A, Huhtaniemi I, Forrest S \& Aittomäki K 2002 A novel mutation in the FSH receptor inhibiting signal transduction and causing primary ovarian failure. Journal of Clinical Endocrinology and Metabolism 87 1151-1155.

Evans BA, Bowen DJ, Smith PJ, Clayton PE \& Gregory JW 1996 A new point mutation in the luteinising hormone receptor gene in familial and sporadic male limited precocious puberty: genotype does not always correlate with phenotype. Journal of Medical Genetics 33 143-147.

Fan QR \& Hendrickson WA 2005 Structure of human follicle-stimulating hormone in complex with its receptor. Nature 433 $269-277$.

Fox KM, Dias JA \& Van Roey P 2001 Three-dimensional structure of human follicle-stimulating hormone. Molecular Endocrinology 15 378-389.

Furui K, Suganuma N, Tsukahara S, Asada Y, Kikkawa F, Tanaka M, Ozawa T \& Tomoda Y 1994 Identification of two point mutations in the gene coding luteinizing hormone (LH) beta-subunit, associated with immunologically anomalous LH variants. Journal of Clinical Endocrinology and Metabolism 78 107-113.

Giacaglia LR, Kohek MBDF, Carvalho FM, Fragoso MC, Mendonca B \& Latronico AC 2000 No evidence of somatic activating mutations on gonadotropin receptor genes in sex cord stromal tumors. Fertility and Sterility 74 992-995.

Greb RR, Grieshaber K, Gromoll J, Sonntag B, Nieschlag E, Kiesel L \& Simoni M 2005 A common single nucleotide polymorphism in exon 10 of the human follicle stimulating hormone receptor is a major determinant of length and hormonal dynamics of the menstrual cycle. Journal of Clinical Endocrinology and Metabolism [in press].

Gromoll J, Simoni M \& Nieschlag E 1996a An activating mutation of the follicle-stimulating hormone receptor autonomously sustains spermatogenesis in a hypophysectomized man. Journal of Clinical Endocrinology and Metabolism 81 1367-1370.

Gromoll J, Simoni M, Nordhoff V, Behre HM, De Geyter C \& Nieschlag E 1996b Functional and clinical consequences of mutations in the FSH receptor. Molecular and Cellular Endocrinology 125 177-182.

Gromoll J, Eiholzer U, Nieschlag E \& Simoni M 2000 Male hypogonadism caused by homozygous deletion of exon 10 of the luteinizing hormone receptor: differential action of the luteinizing hormone (LH) and human chrionic gonadotropin (hCG). Journal of Clinical Endocrinology and Metabolism 85 2281-2286.
Gromoll J, Schulz A, Borta H, Gudermann T, Teerds KJ, Greschniok A, Nieschlag E \& Seif FJ 2002 Homozygous mutation within the conserved Ala-Phe-Asn-Glu-Thr motif of exon 7 of the $\mathrm{LH}$ receptor causes male pseudohermaphroditism. European Journal of Endocrinology 147 597-608.

Guo S, Russo IH, Lareef MH \& Russo J 2004 Effect of human chorionic gonadotropin in the gene expression profile of MCF-7 cells. International Journal of Oncology 24 399-407.

Hasbargen U, Thaler CJ, Ruebsamen H, Fuchshuber S \& Lohse P 2001 S680N substitution of the follicle-stimulating hormone receptor is a common polymorphism not associated with spontaneous human twinning. European Journal of Medical Research 6 $315-316$

Ignacak M, Hilczer M, Zarzycki J \& Trzeciak WH 2000 Substitution of M398T in the second transmembrane helix of the LH receptor in a patient with familial male-limited precocious puberty. Endocrine Journal 47 595-599.

Ignacak M, Starzyk J, Dziatkowiak H \& Trzeciak WH 2002 Study of the family of a patient with male-limited precocious puberty (MPP) due to T1193C transition in exon 11 of LH receptor gene. Journal of Endocrinological Investigation 25 259-263.

Jiang $\mathbf{M}$, Lamminen $\mathrm{T}$, Pakarinen P, Hellman J, Manna P, Herrera RJ \& Huhtaniemi I 2002 A novel Ala(-3)Thr mutation in the signal peptide of human luteinizing hormone beta-subunit: potentiation of the inositol phosphate signalling pathway and attenuation of the adenylate cyclase pathway by recombinant variant hormone. Molecular Human Reproduction 8 201-212.

Jiang $\mathbf{M}$, Savontaus $\mathrm{ML}$, Simonsen $\mathbf{H}$, Williamson $\mathbf{C}$, Mullenbach $\mathbf{R}$, Gromoll J, Terwort N, Alevizaki M \& Huhtaniemi I 2004 Absence of the genetic variant Val79Met in human chorionic gonadotropinbeta gene 5 in five European populations. Molecular Human Reproduction $10763-766$.

Jiang $X$, Dreano $M$, Buckler DR, Cheng $S$, Ythier $A$, Wu $\mathbf{H}$, Hendrickson WA \& el Tayar N 1995 Structural predictions for the ligand-binding region of glycoprotein hormone receptors and the nature of hormone-receptor interactions. Structure 3 1341-1353.

Kaiser UB 2003 The pathogenesis of the ovarian hyperstimulation syndrome. New England Journal of Medicine 349 729-732.

Kajava AV, Vassart G \& Wodak SJ 1995 Modeling of the threedimensional structure of proteins with the typical leucine-rich repeats. Structure $3867-877$.

Kim NK, Nam YS, Ko JJ, Chung HM, Chung KW \& Cha KY 2001 The luteinizing hormone beta-subunit exon 3 (Gly102Ser) gene mutation is rare in Korean women with endometriosis and polycystic ovary syndrome. Fertility and Sterility 75 1238-1239.

Kobe B \& Deisenhofer J 1993 Crystal structure of porcine ribonuclease inhibitor, a protein with leucine-rich repeats. Nature 366 $751-756$.

Kobe B \& Kajava AV 2001 The leucine-rich repeat as a protein recognition motif. Current Opinion in Structural Biology 11 725-732.

Lamminen T, Jiang M, Manna PR, Pakarinen P, Simonsen H, Herrera RJ \& Huhtaniemi I 2002 Functional study of a recombinant form of human LHbeta-subunit variant carrying the Gly(102)Ser mutation found in Asian populations. Molecular Human Reproduction 8 887-892.

Lapthorn AJ, Harris DC, Littlejohn A, Lustbader JW, Canfield RE, Machin KJ, Morgan FJ \& Isaacs NW 1994 Crystal structure of human chorionic gonadotropin. Nature 369 455-461.

Latronico AC, Shinozaki H, Guerra G Jr, Pereira MA, Lemos Marini SH, Baptista MT, Arnhold IJ, Fanelli F, Mendonca BB \& Segaloff DL 2000 Gonadotropin-independent precocious puberty due to luteinizing hormone receptor mutations in Brazilian boys: a novel constitutively activating mutation in the first transmembrane helix. Journal of Clinical Endocrinology and Metabolism $\mathbf{8 5}$ 4799-4805.

Laue L, Chan WY, Hsueh AJ, Kudo M, Hsu SY, Wu SM, Blomberg L \& Cutler GB Jr 1995 Genetic heterogeneity of constitutively activating mutations of the human luteinizing hormone receptor in familial male-limited precocious puberty. PNAS 92 1906-1910. 
Laue L, Wu SM, Kudo M, Hsueh AJW, Cutler GB Jr, Jelly DH, Diamond FB \& Chan WY 1996 Heterogeneity of activating mutations of the human luteinizing hormone receptor in male-limited precocious puberty. Biochemical and Molecular Medicine $\mathbf{5 8}$ $192-198$.

Laven JS, Mulders AG, Suryandari DA, Gromoll J, Nieschlag E, Fauser BC \& Simoni M 2003 Follicle-stimulating hormone receptor polymorphisms in women with normogonadotropic anovulatory infertility. Fertility and Sterility 80 986-992.

Layman LC, Porto AL, Xie J, da Motta LA, da Motta LD, Weiser W \& Sluss PM 2002 FSH beta gene mutations in a female with partial breast development and a male sibling with normal puberty and azoospermia. Journal of Clinical Endocrinology and Metabolism $873702-3707$.

Lee S, Kim NK, Kim HJ, Lee SH, Jeong HJ \& Cha KY 2003 Genetic analysis of three polymorphic sites of the luteinizing hormone beta-subunit gene in infertile Korean men with nonobstructive azoospermia. Fertility and Sterility 79 517-521.

Leung MY, Al-Muslim O, Wu SM, Aziz A, Inam S, Awadh M, Rennert OM \& Chan WY 2004 A novel missense homozygous inactivating mutation in the fourth transmembrane helix of the luteinizing hormone receptor in Leydig cell hypoplasia. American Journal of Medical Genetics 130A 146-153.

Lindstedt G, Nystrom E, Matthews C, Ernest I, Janson PO \& Chatterjee K 1998 Follitropin (FSH) deficiency in an infertile male due to FSHbeta gene mutation. A syndrome of normal puberty and virilization but underdeveloped testicles with azoospermia, low FSH but high lutropin and normal serum testosterone concentrations. Clinical Chemistry and Laboratory Medicine 36 663-665.

Liu G, Duranteau L, Carel JC, Monroe J, Doyle DA \& Shenker A 1999 Leydig-cell tumors caused by an activating mutation of the gene encoding the luteinizing hormone receptor. New England Journal of Medicine 341 1731-1736.

Manna PR, Joshi L, Reinhold VN, Aubert ML, Suganuma N, Pettersson K \& Huhtaniemi IT 2002 Synthesis, purification and structural and functional characterization of recombinant form of a common genetic variant of human luteinizing hormone. Human Molecular Genetics 11 301-315.

Martens JW, Lumbroso S, Verhoef-Post M, Georget V, Richter-Unruh A, Szarras-Czapnik M, Romer TE, Brunner HG, Themmen AP \& Sultan C 2002 Mutant luteinizing hormone receptors in a compound heterozygous patient with complete Leydig cell hypoplasia: abnormal processing causes signaling deficiency. Journal of Clinical Endocrinology and Metabolism 87 2506-2513.

Matthews $\mathrm{CH}$, Borgato $\mathrm{S}$, Beck-Peccoz $\mathrm{P}$, Adams $\mathrm{M}$, Tone $\mathrm{Y}$, Gambino G, Casagrande S, Tedeschini G, Benedetti A \& Chatterjee VK 1993 Primary amenorrhoea and infertility due to a mutation in the beta-subunit of follicle-stimulating hormone. Nature Genetics 5 83-86.

Meduri G, Touraine P, Beau I, Lahuna O, Desroches A, VacherLavenu MC, Kuttenn F \& Misrahi M 2003 Delayed puberty and primary amenorrhea associated with a novel mutation of the human follicle-stimulating hormone receptor: clinical, histological, and molecular studies. Journal of Clinical Endocrinology and Metabolism 88 3491-3498.

Miller-Lindholm AK, Bedows E, Bartels CF, Ramey J, Maclin V \& Ruddon RW 1999 A naturally occurring genetic variant in the human chorionic gonadotropin-beta gene 5 is assembly inefficient. Endocrinology 140 3496-3506.

Montanelli L, Delbaere A, Di Carlo C, Nappi C, Smits G, Vassart G \& Costagliola S 2004 A mutation in the follicle-stimulating hormone receptor as a cause of familial spontaneous ovarian hyperstimulation syndrome. Journal of Clinical Endocrinology and Metabolism 89 1255-1258.

Montgomery GW, Duffy DL, Hall J, Haddon BR, Kudo M, McGee EA, Palmer JS, Hsueh AJ, Boomsma DI \& Martin NG 2000 Dizygotic twinning is not linked to variation at the alpha-inhibin locus on human chromosome 2. Journal of Clinical Endocrinology and Metabolism $853391-3395$.
Muller T, Gromoll J \& Simoni M 2003 Absence of exon 10 of the human luteinizing hormone $(\mathrm{LH})$ receptor impairs $\mathrm{LH}$, but not human chorionic gonadotropin action. Journal of Clinical Endocrinology and Metabolism 88 2242-2249.

Muller T, Simoni M, Pekel E, Luetjens CM, Chandolia R, Amato $F$ Norman RJ \& Gromoll J 2004 Chorionic gonadotrophin beta subunit mRNA but not luteinising hormone beta subunit mRNA is expressed in the pituitary of the common marmoset (Callithrix jacchus). Journal of Molecular Endocrinology 32 115-128.

Okuno A, Komori S, Sakata K, Nakata Y, Tsuji Y, Koyama K \& Kameda T 2001 Genetic analysis of a variant luteinizing hormone in an infertile woman. Archives of Gynecology and Obstetrics 265 148-150.

Palczewski K, Kumasaka T, Hori T, Behnke CA, Motoshima H, Fox BA, Le Trong I, Teller DC, Okada T, Stenkamp RE, Yamamoto M \& Miyano M 2000 Crystal structure of rhodopsin: a G proteincoupled receptor. Science 289 739-745.

Perez Mayorga M, Gromoll J, Behre HM, Gassner C, Nieschlag E \& Simoni M 2000 Ovarian response to follicle-stimulating hormone (FSH) stimulation depends on the FSH receptor genotype. Journal of Clinical Endocrinology and Metabolism 85 3365-3369.

Pettersson K, Ding YQ \& Huhtaniemi I 1992 An immunologically anomalous luteinizing hormone variant in a healty woman. Journal of Clinical Endocrinology and Metabolism 74 164-171.

Pettersson K, Makela MM, Dahlen P, Lamminen T, Huoponen K \& Huhtaniemi I 1994 Genetic polymorphism found in the LH beta gene of an immunologically anomalous variant of human luteinizing hormone. European Journal of Endocrinology 130 Suppl 265.

Phillip M, Arbelle JE, Segev Y \& Parvari R 1998 Male hypogonadism due to a mutation in the gene for the beta-subunit of follicle-stimulating hormone. New England Journal of Medicine $\mathbf{3 3 8}$ 1729-1732.

Powell BL, Piersma D, Kevenaar ME, van Staveren IL, Themmen AP, lacopetta BJ \& Berns EM 2003 Luteinizing hormone signaling and breast cancer: polymorphisms and age of onset. Journal of Clinical Endocrinology and Metabolism 88 1653-1657.

Ramanujam LN, Liao WX, Roy AC \& Ng SC 2000 Association of molecular variants of luteinizing hormone with male infertility. Human Reproduction 15 925-928.

Rannikko A, Pakarinen P, Manna PR, Beau I, Misrahi M, Aittomäki K \& Huhtaniemi I 2002 Functional characterization of the human FSH receptor with an inactivating Ala189Val mutation. Molecular Human Reproduction 8 311-317.

Remy JJ, Nespoulous C, Grosclaude J, Grebert D, Couture L, Pajot E \& Salesse R 2001 Purification and structural analysis of a soluble human chorionogonadotropin hormone-receptor complex. Journal of Biological Chemistry 276 1681-1687.

Richter-Unruh A, Martens JW, Verhoef-Post M, Wessels HT, Kors WA, Sinnecker GH, Boehmer A, Drop SL, Toledo SP, Brunner HG \& Themmen AP 2002a Leydig cell hypoplasia: cases with new mutations, new polymorphisms and cases without mutations in the luteinizing hormone receptor gene. Clinical Endocrinology $\mathbf{5 6}$ 103-112.

Richter-Unruh A, Wessels HT, Menken U, Bergmann $M$, Schmittmann-Ohters K, Schaper J, Tappeser S \& Hauffa BP 2002b Male LH-independent sexual precocity in a 3.5-year-old boy caused by a somatic activating mutation of the $\mathrm{LH}$ receptor in a Leydig cell tumor. Journal of Clinical Endocrinology and Metabolism 87 1052-1056.

Richter-Unruh A, Korsch E, Hiort O, Holterhus PM, Themmen AP \& Wudy SA 2005 Novel insertion frameshift mutation of the LH receptor gene: problematic clinical distinction of Leydig cell hypoplasia from enzyme defects primarily affecting testosterone biosynthesis. European Journal of Endocrinology 152 255-259.

Rodien P, Bremont C, Sanson ML, Parma J, Van Sande J, Costagliola S, Luton JP, Vassart G \& Duprez L 1998 Familial gestational hyperthyroidism caused by a mutant thyrotropin receptor hypersensitive to human chorionic gonadotropin. New England Journal of Medicine 339 1823-1826. 
Rodien P, Cetani F, Costagliola S, Tonacchera M, Duprez L, Minegishi T, Govaerts C \& Vassart G 1998 Evidences for an allelic variant of the human LC/CG receptor rather than a gene duplication: functional comparison of wild-type and variant receptors. Journal of Clinical Endocrinology and Metabolism 83 4431-4434.

Rosenthal IM, Refetoff S, Rich B, Barnes RB, Sunthornthepvarakul T, Parma J \& Rosenfield RL 1996 Response to challenge with gonadotropin-releasing hormone agonist in a mother and her two sons with a constitutively activating mutation of the luteinizing hormone receptor - a clinical research center study. Journal of Clinical Endocrinology and Metabolism 81 3802-3806.

Salameh W, Choucair M, Guo TB, Zahed L, Wu SM, Leung MY, Rennert OM \& Chan WY 2005 Leydig cell hypoplasia due to inactivation of luteinizing hormone receptor by a novel homozygous nonsense truncation mutation in the seventh transmembrane domain. Molecular and Cellular Endocrinology 229 57-64.

Shenker A, Laue L, Kosugi S, Merendino JJ Jr, Minegishi T \& Cutler GB Jr 1993 A constitutively activating mutation of the luteinizing hormone receptor in familial male precocious puberty. Nature $\mathbf{3 6 5}$ 652-654.

Simoni M, Gromoll J, Hoppner W, Kamischke A, Krafft T, Stahle D \& Nieschlag E 1999 Mutational analysis of the follicle-stimulating hormone $(\mathrm{FSH})$ receptor in normal and infertile men: identification and characterization of two discrete FSH receptor isoforms. Journal of Clinical Endocrinology and Metabolism 84 751-755.

Simoni M, Nieschlag E \& Gromoll J 2002 Isoforms and single nucleotide polymorphisms of the FSH receptor gene: implications for human reproduction. Human Reproduction Update 8 413-421.

Smits G, Olatunbosun O, Delbaere A, Pierson R, Vassart G \& Costagliola S 2003 Ovarian hyperstimulation syndrome due to a mutation in the follicle-stimulating hormone receptor. New England Journal of Medicine 349 760-766.

Sudo S, Kudo M, Wada S, Sato O, Hsueh AJ \& Fujimoto S 2002 Genetic and functional analyses of polymorphisms in the human FSH receptor gene. Molecular Human Reproduction 8 893-899.

Sundblad V, Chiauzzi VA, Escobar ME, Dain L \& Charreau EH 2004 Screening of FSH receptor gene in Argentine women with premature ovarian failure (POF). Molecular and Cellular Endocrinology $22253-59$.

Szkudlinski MW, Fremont V, Ronin C \& Weintraub BD 2002 Thyroid-stimulating hormone and thyroid-stimulating hormone receptor structure-function relationships. Physiology Reviews 82 473-502.

Takahashi K, Kurioka H, Kanasaki H, Okada M, Ozaki T \& Miyazaki K 2000 A case of a pregnant woman with luteal insufficiency and a mutation in the beta-subunit of luteinizing hormone. International Journal of Fertility and Womens Medicine 45 327-334.

Takahashi K, Kurioka H, Ozaki T, Kanasaki H, Miyazaki K \& Karino K 2000 Pituitary response to luteinizing hormone-releasing hormone in women with variant luteinizing hormone. European Journal of Endocrinology 143 375-381.

Takahashi K, Ozaki T, Kanasaki H \& Miyazaki K 2001 Successful pregnancy in a woman with ovarian failure associated with mutation in the beta-subunit of luteinizing hormone. Hormone Research 55 258-263.

Takakura K, Takebayashi K, Wang HQ, Kimura F, Kasahara K \& Noda Y 2001 Follicle-stimulating hormone receptor gene mutations are rare in Japanese women with premature ovarian failure and polycystic ovary syndrome. Fertility and Sterility 75 207-209.

Tao YX, Abell AN, Liu X, Nakamura K \& Segaloff DL 2000 Constitutive activation of $\mathrm{G}$ protein-coupled receptors as a result of selective substitution of a conserved leucine residue in transmembrane helix III. Molecular Endocrinology 14 1272-1282.

Tapanainen JS, Aittomäki K, Min J, Vaskivuo T \& Huhtaniemi IT 1997 Men homozygous for an inactivating mutation of the follicle-stimulating hormone (FSH) receptor gene present variable suppression of spermatogenesis and fertility. Nature Genetics 15 205-206.

Themmen APN \& Huhtaniemi I 2000 Mutations of gonadotropins and gonadotropin receptors: elucidating the physiology and pathophysiology of pituitary-gonadal function. Endocrine Reviews 21 $551-583$.

Tong Y, Liao WX, Roy AC \& Ng SC 2001 Absence of mutations in the coding regions of follicle-stimulating hormone receptor gene in Singapore Chinese women with premature ovarian failure and polycystic ovary syndrome. Hormone and Metabolism Research $33221-226$.

Touraine P, Beau I, Gougeon A, Meduri G, Desroches A, Pichard C, Detoeuf M, Paniel B, Prieur M, Zorn JR, Milgrom E, Kuttenn F \& Misrahi M 1999 New natural inactivating mutations of the folliclestimulating hormone receptor: correlations between receptor function and phenotype. Molecular Endocrinology 13 1844-1854.

Valdes-Socin H, Salvi R, Daly AF, Gaillard RC, Quatresooz P, Tebeu PM, Pralong FP \& Beckers A 2004 Hypogonadism in a patient with a mutation in the luteinizing hormone beta-subunit gene. New England Journal of Medicine 351 2619-2625.

Vaskivuo TE, Aittomäki $K$, Anttonen $M$, Ruokonen A, Herva R, Osawa Y, Heikinheimo M, Huhtaniemi I \& Tapanainen JS 2002 Effects of follicle-stimulating hormone (FSH) and human chorionic gonadotropin in individuals with an inactivating mutation of the FSH receptor. Fertility and Sterility 78 108-113.

Vasseur C, Rodien P, Beau I, Desroches A, Gerard C, de Poncheville L, Chaplot S, Savagner F, Croue A, Mathieu E, Lahlou N, Descamps P \& Misrahi M 2003 A chorionic gonadotropin-sensitive mutation in the follicle-stimulating hormone receptor as a cause of familial gestational spontaneous ovarian hyperstimulation syndrome. New England Journal of Medicine 349 753-759.

Vieira TC, Cerutti JM, Dias da Silva MR, Delcelo R \& Abucham J 2002 Absence of activating mutations in the hot spots of the LH receptor and Gs-alpha genes in Leydig cell tumors. Journal of Endocrinological Investigation 25 598-602.

Weiss J, Axelrod L, Whitcomb RW, Harris PE, Crowley WF \& Jameson JL 1992 Hypogonadism caused by a single amino acid substitution in the beta subunit of luteinizing hormone. New England Journal of Medicine 326 179-183.

Zhang FP, Rannikko AS, Manna PR, Fraser HM \& Huhtaniemi IT 1997 Cloning and functional expression of the luteinizing hormone receptor complementary deoxyribonucleic acid from the marmoset monkey testis: absence of sequences encoding exon 10 in other species. Endocrinology 138 2481-2490.

Received 27 May 2005

First decision 28 June 2005

Accepted 28 June 2005 